\section{Postharvest Evaluation of Cut Dahlia, Linaria, Lupine, Poppy, Rudbeckia, Trachelium, and Zinnia}

\author{
John M. Dole ${ }^{1,4}$, Zenaida Viloria ${ }^{2}$, Frankie L. Fanelli ${ }^{3}$, \\ and William Fonteno ${ }^{1}$
}

ADDITIONAL INDEX WORDS. hydrator, preservative, cold storage, ethylene sensitivity, 1-MCP, silver thiosulfate, sucrose

Summary. Vase life of 'Karma Thalia' dahlia (Dablia $\times$ bybrida), 'Lace Violet' linaria (Linaria maroccana), 'Sunrise' lupine (Lupinus hartwegii ssp. cruickshankii), 'Temptress' poppy (Papaver nudicaule), 'Indian Summer' rudbeckia (Rudbeckia $\times$ bybrida), 'Jemmy Royal Purple' trachelium (Trachelium caeruleum), and 'Benary's Giant Scarlet' and 'Sun Gold' zinnias (Zinnia elegans) was determined after being subjected to postharvest handling procedures. Cut dahlia, lupine, poppy, rudbeckia, trachelium, and 'Sun Gold' and 'Benary's Giant Scarlet' zinnia flowers could be held in unamended tap or deionized (DI) water with no effect on vase life. Vase life of linaria was longest when placed in DI water with 8-hydroxyquinoline citrate and a solution $\mathrm{pH}$ of 3.5 . A vase solution of $2 \%$ sucrose without foam extended consumer vase lives for linaria, trachelium, and 'Benary's Giant Scarlet' zinnia. Floral foam or $2 \%$ or $4 \%$ sucrose had no effect on the consumer vase life of dahlia, lupine, rudbeckia, and poppy. Trachelium and rudbeckia did not tolerate a $20 \%$ sucrose treatment for $24 \mathrm{~h}$, whereas linaria and 'Benary's Giant Scarlet' zinnia had a longer vase life with a $10 \%$ sucrose pulse than a water-only pulse. For trachelium, the longest (17.5 days) consumer vase life occurred when the Chrysal Professional 2 Processing solution (CP2) was used after pretreatment with DI water. Either of two commercial holding solutions, CP2 or Floralife Professional (FLP), similarly extended the vase life of linaria. The use of FLP or CP2 improved consumer vase life of dahlia, lupine, and poppy compared with DI water. Dahlia, trachelium, and zinnia flowers could not be cold stored at $2{ }^{\circ} \mathrm{C}$. Lupine and poppy could be stored at $2{ }^{\circ} \mathrm{C}$ wet or dry for 2 weeks. Linaria and rudbeckia could be cold stored for 3 weeks. Lupine and trachelium were susceptible to $1 \mu \mathrm{L} \cdot \mathrm{L}^{-1}$ exogenous ethylene, which induced floret abscission in lupine and stopped floret opening in trachelium. 1Methylcyclopropene and silver thiosulfate similarly suppressed the ethylene effect. Cut linaria, zinnia, dahlia, rudbeckia, and poppy flowers were unaffected by exogenous ethylene.

S pecialty cut flowers comprise a large number of species, including trees, shrubs, and herbaceous annuals and perennials. Two key aspects of the specialty cut flower industry are introducing new species and marketing flowers with a long postharvest life. Interesting new cut flower species excite buyers and increase sales, and a long postharvest life ensures

Department of Horticultural Science, North Carolina State University, Raleigh, NC 27695-7609

We gratefully acknowledge support from the American Floral Endowment, Association of Specialty Cut Flower Growers Research Foundation, and numerous suppliers.

We would like to thank Ingram McCall for producing the cut flowers and assisting with the postharvest studies, and Beth Harden and Diane Mays for assisting with the postharvest studies.

${ }^{1}$ Professor.

${ }^{2}$ Postdoctoral Research Assistant.

${ }^{3}$ Graduate Research Technician.

${ }^{4}$ Corresponding author. E-mail: john_dole@ncsu.edu. that the customers-wholesalers, retailers, and the final consumer-will be satisfied and return to purchase more flowers.

Of the many cut flowers introduced to commercial markets each year, several show potential. 'Lace Violet' linaria, 'Sunrise' lupine, 'Temptress' poppy, and 'Indian Summer' rudbeckia are new species for the cut flower industry. 'Karma Thalia' dahlia, 'Jemmy Royal Purple' trachelium, and 'Sun Gold' and 'Benary's Giant Scarlet' zinnias are established species in the cut flower industry, but the cultivars are new. The lack of information about postharvest handling of the above-listed species and cultivars makes it necessary to develop efficient and practical techniques for flower producers, wholesalers, and retailers to enhance quality and longevity.

The available literature describing how vase water quality affects cut flower quality is variable, and recommendations differ regarding the use of tap or deionized (DI) water (Nowak and Rudnicki, 1990; Sacalis, 1993). In some studies, tap water produced the shortest vase life (Kamataka, 2003), but in others, it resulted in a longer vase life than DI water (van Meeteren et al., 2000).

Adding sucrose, typically through the use of commercial premixed products, to the vase solution enhanced postharvest performance and flower quality of many species (Cho et al., 2001; Jones et al., 1993; Sacalis, 1993). Incorporating biocides in the vase solutions decreases microbial growth and therefore maintains healthier vascular tissue. Results may be cultivar specific as vase life of 'Florex Gold' calla lily (Zantedeschia elliottiana) was extended after a 2 -h pulse in 8-hydroxyquinoline citrate (8-HQC), while the same treatment reduced longevity and quality in 'Black Magic' calla lily (Janowska and Jerzy, 2004). A 24-h pulse in 8-HQC increased the longevity of sunflower (Helianthus annuus) and weigela (Weigela spp.) but reduced the vase life of yarrow (Achillea) (Redman et al., 2002).

\begin{tabular}{llll}
\hline $\begin{array}{l}\text { Units } \\
\begin{array}{l}\text { To convert U.S. to SI, } \\
\text { multiply by }\end{array}\end{array}$ & U.S. unit & SI unit & $\begin{array}{l}\text { To convert SI to U.S., } \\
\text { multiply by }\end{array}$ \\
\hline 29.5735 & $\mathrm{fl} \mathrm{oz}$ & $\mathrm{mL}$ & 0.0338 \\
0.3048 & $\mathrm{ft}$ & $\mathrm{m}$ & 3.2808 \\
3.7854 & $\mathrm{gal}$ & $\mathrm{L}$ & 0.2642 \\
2.54 & inch $(\mathrm{es})$ & $\mathrm{cm}$ & 0.3937 \\
1 & $\mathrm{mmho} / \mathrm{cm}$ & $\mathrm{dS} \cdot \mathrm{m}^{-1}$ & 1 \\
28,350 & $\mathrm{oz}$ & $\mathrm{mg}$ & $3.5274 \times 10^{-5}$ \\
1 & $\mathrm{ppb}$ & $\mathrm{nL} \cdot \mathrm{L}^{-1}$ & 1 \\
1 & $\mathrm{ppm}$ & $\mathrm{mg} \cdot \mathrm{L}^{-1}$ & 1 \\
0.001 & $\mathrm{ppm}$ & $\mathrm{mL} \cdot \mathrm{L}^{-1}$ & 1000 \\
1 & $\mathrm{ppm}$ & $\mu \mathrm{LL} \cdot \mathrm{L}^{-1}$ & 1 \\
$\left({ }^{\circ} \mathrm{F}-32\right) \div 1.8$ & ${ }^{\circ} \mathrm{F}$ & ${ }^{\circ} \mathrm{C}$ & $\left(1.8 \times{ }^{\circ} \mathrm{C}\right)+32$
\end{tabular}


The ability for new cuts to perform well in floral foam is important, especially to florists. Generally, when flowers are placed in floral foam, the vase life is decreased (Sacalis, 1993), but cut big bend bluebonnet (Lupinus havardii) stems performed as well in floral foam as in water (Davis et al., 1995).

Cold storage is used to delay cut flower development and provide a long vase life (Cevallos and Reid, 2001; Faragher et al., 1984; Redman et al., 2002). In addition, antiethylenebinding products have been successfully used on ethylene-sensitive species (Geertsen, 1990; Ichimura et al., 1998; Newman et al., 1998; Reid, 2004), but they have no effect on extending vase life of nonsensitive species (Elgar et al., 1999; Kenza et al., 2000).

The objective of this study was to evaluate water type, concentrated sucrose vase solutions, floral foam, commercial hydrators and holding solutions, cold storage, and ethylene sensitivity as components of the postharvest handling of seven specialty cut flowers.

\section{Materials and methods}

Cut STEM production. 'Lace Violet' linaria, 'Sunrise' lupine, 'Temptress' poppy, and 'Jemmy Royal Purple' trachelium plants were grown in a polyethylene-covered greenhouse using a peat-based commercial root substrate (Fafard 4P; Conrad Fafard, Agawam, MA). Linaria were directly sown on 18 Nov. 2002 into 806 bedding plant flats $(35 \mathrm{~mL}$ volume per cell) and were germinated at $16 \pm$ $1{ }^{\circ} \mathrm{C}$. Linaria seedlings were transplanted on 17 Dec. 2002 into 4-inchdiameter $(325 \mathrm{~mL})$ pots spaced at $4 \times$ 4 inches. Trachelium seeds were sown into open flats on 7 Jan. 2004 and were transplanted on 4 March into 806 bedding plant flats, which were then transplanted on 3 May to standard bulb crates $(52 \times 38 \mathrm{~cm}, 11 \mathrm{~cm}$ deep $)$ in a $4 \times 5$ arrangement $(7.5 \times$ $9.5 \mathrm{~cm}$ apart). Lupine seeds were directly sown on 25 Feb. 2004 into 6 -inch-diameter $(1160 \mathrm{~mL})$ pots spaced at $6 \times 6$ inches. Poppy seedlings were received from a commercial grower and were transplanted on 7 Jan. 2003 into 6-inch- diameter $(1160 \mathrm{~mL})$ pots spaced at $12 \times 12$ inches.

Linaria and poppy seedlings were grown at $10 \pm 1.1{ }^{\circ} \mathrm{C}$ night temperatures, with day temperatures averaging $24 \pm 1.6^{\circ} \mathrm{C}$. Lupine seedlings were grown at $15 \pm 1.2^{\circ} \mathrm{C}$ night temperatures, with day temperatures averaging $24 \pm 1.5^{\circ} \mathrm{C}$. Trachelium seedlings were grown at $15 \pm 1.7^{\circ} \mathrm{C}$ night temperatures, with day temperatures averaging $27 \pm 1.6^{\circ} \mathrm{C}$.

Plants were irrigated as needed with $150 \mathrm{mg} \cdot \mathrm{L}^{-1} \mathrm{~N}$ from $20 \mathrm{~N}-4.4 \mathrm{P}-$ 16.6K fertilizer (Peter's Professional 20-10-20; Scott's, Marysville, OH) during the week and with unamended tap water on the weekends. Linaria stems were harvested from 8 March to 2 Apr. 2003, lupine from 7 Apr. to 7 May 2004, poppy from 27 March to 17 Apr. 2003, and trachelium from 17 June to 19 July 2004.
'Karma Thalia' dahlia, 'Indian Summer' rudbeckia, and 'Sun Gold' and 'Benary's Giant Scarlet' zinnia plants were field grown at $30 \times 30$ $\mathrm{cm}$ spacing in a 4 -ft-wide bed. Rooted dahlia cuttings were received from a commercial propagator and were planted in the field on 29 Apr. 2003. Rudbeckia and zinnia seeds were directly sown on $28 \mathrm{Jan}$. and 30 Mar. 2003, respectively, into 806 bedding plant flats $(35 \mathrm{~mL}$ volume per cell) using a peat-based commercial root substrate (Fafard 4P). Seeds were germinated at $16 \pm 1{ }^{\circ} \mathrm{C}$ in a polyethylene-covered greenhouse. Seedlings were transplanted into the field on 20 March (rudbeckia) and 27 Apr. (zinnia). Plants were irrigated as needed with $100 \mathrm{mg} \cdot \mathrm{L}^{-1} \mathrm{~N}$ from 20N-4.4P-16.6K fertilizer (Peter's Professional 20-10-20). Dahlia stems were harvested from 12 Aug. to 12 Sept. 2003, rudbeckia stems from 1 July to 26 July 2003 , and zinnia stems from 17 June to 12 July 2004.

Stems were harvested according to criteria set for each species (Table 1 ); placed into buckets of tap water ( $\mathrm{pH}$ 6.3-7.1; EC 0.18-0.23 dS $\cdot \mathrm{m}^{-1}$ ); sorted into similar groups based on stem length and diameter, flower bud number and flower size, as appropriate for the species; re-cut; and subjected to appropriate experimental treatments. Stem length after recutting was $30 \mathrm{~cm}$ for most species except linaria $(45 \mathrm{~cm})$ and zinnia $(30$ or $36 \mathrm{~cm}$ ).

Control solutions. Cut stems were held in DI water $(\mathrm{pH} 3.1-4.2$;

Table 1. Harvest and vase life termination criteria for cut dahlia, linaria, lupine, poppy, rudbeckia, trachelium, and zinnia stems.

\begin{tabular}{|c|c|c|c|}
\hline \multirow[b]{2}{*}{ Species } & \multirow[b]{2}{*}{ Harvest stage } & \multicolumn{2}{|c|}{ Vase life termination criteria } \\
\hline & & Retail vase life & Consumer vase life \\
\hline Dahlia & $\begin{array}{l}\text { Two to several outer rows } \\
\text { of petals fully expanded. }\end{array}$ & Not recorded. & $\begin{array}{l}\text { Browning on the petals was noticeable } \\
\text { when looking directly at the flower head. }\end{array}$ \\
\hline Linaria & Two to four open florets. & $\begin{array}{l}\text { Immature florets opened } \\
\text { pale or more than } 50 \% \text { of } \\
\text { the spike opened. }\end{array}$ & $\begin{array}{l}\text { Stem collapsed or more than } 75 \% \text { of florets } \\
\text { were discolored or shriveled. }\end{array}$ \\
\hline Poppy & Calyx cracked and petals visible. & $\begin{array}{l}\text { Petals opened enough that } \\
\text { the flowers no longer had a } \\
\text { cup shape. }\end{array}$ & $\begin{array}{l}\text { Petals shattered or become crinkled, discolored, } \\
\text { or brown, or the stem collapsed. }\end{array}$ \\
\hline Rudbeckia & Outer petals were fully open. & Not recorded. & Stem collapsed or the petals began to turn brown. \\
\hline Trachelium & $25 \%$ open florets in a head. & $\begin{array}{l}\text { Florets were no longer uniform } \\
\text { in appearance. }\end{array}$ & $\begin{array}{l}\text { Florets turned brown or the florets } \\
\text { closed and/or did not continue to open. }\end{array}$ \\
\hline
\end{tabular}


EC $\left.0 \mathrm{dS} \cdot \mathrm{m}^{-1}\right)$, DI water supplemented with $200 \mathrm{mg} \cdot \mathrm{L}^{-1}$ 8-HQC ( $\mathrm{pH}$ 2.8-3.1; EC 0.12-0.15 dS. $\mathrm{m}^{-1}$ ), tap water ( $\mathrm{pH} 6.3-7.1 ;$ EC $0.18-0.23$ $\mathrm{d} S \cdot \mathrm{m}^{-1}$ ), or tap water with 8 -HQC ( $\mathrm{pH} 3.5-4.5$; EC $\left.0.26-0.34 \mathrm{dS} \cdot \mathrm{m}^{-1}\right)$. In addition, the $\mathrm{pH}$ of DI solutions was adjusted to 3.5 using citric acid and compared with non-pH-adjusted solutions.

Sucrose and VASE substrate. Cut stems were placed into vases containing sucrose at $0 \%, 2 \%$, or $4 \%$ dissolved in DI water, with or without floral foam (Oasis Floral Foam, Smithers-Oasis, Kent, OH). Before insertion of the stems, foam was soaked in the appropriate sucrose solution for $4 \mathrm{~h}$.

SuCrose PULSE. Cut stems were pulsed in DI water amended with sucrose at $0 \%, 10 \%$, or $20 \%$ for $24 \mathrm{~h}$ at $20 \pm 1{ }^{\circ} \mathrm{C}$ in the dark. Thereafter, stems were transferred to floral vases containing DI water.

COMMERCIAL HYDRATOR AND PRESERVATIVE TREATMENTS. Cut linaria, trachelium, and 'Benary's Giant Scarlet' and 'Sun Gold' zinnia stems were initially pulsed in a commercial hydrator solution [Chrysal Professional 1 ( $\mathrm{CPl}$ ) Hydrating Solution (Bendien, Naarden, The Netherlands) or Floralife Hydraflor 100 (FL100) (Floralife ${ }^{\circledR}$, Walterboro, SC)] at 2 and $5 \mathrm{~mL} \cdot \mathrm{L}^{-1}$, respectively, or DI water for $4 \mathrm{~h}$ at $5{ }^{\circ} \mathrm{C}$ in the dark. Thereafter, stems were placed into floral vases containing a commercial holding solution [Chrysal Professional 2 Processing solution (CP2) or Floralife Professional (FLP)] at 10 $\mathrm{mL} \cdot \mathrm{L}^{-1}$ each or DI water. For dahlia, lupine, poppy, and rudbeckia, hydrator or commercial preservative treatments were evaluated separately, not in combinations. Unamended DI water was used as a control solution for hydrator and preservative treatments.

Cold storage. For dry storage, cut stems were placed in cardboard floral boxes lined with newspaper. Buckets filled with DI water were used for wet storage. All stems were stored in a cooler at $2{ }^{\circ} \mathrm{C}$ and $80 \%$ to $90 \%$ relative humidity in the dark. Fifteen stems were randomly selected from dry and wet storage treatments after 1,2 , or 3 weeks to evaluate the vase life. Unstored stems were assessed for vase life as a control treatment. All stems were recut under water after storage and placed into floral vases.

Ethylene SENSITIVITy. Cut stems were pulsed with $0.2 \mathrm{~mm}$ silver thiosulfate (STS) $\left[1 \mathrm{~mL} \cdot \mathrm{L}^{-1}\right.$ Chrysal AVB (Pokan \& Chrysal, Miami, FL)], 1-methylcyclopropene (MCP) [400 mg Ethylbloc ${ }^{\mathrm{TM}}$ (Agrofresh, Spring House, Philadelphia) dissolved in 50 $\mathrm{mL}$ of DI water at $30{ }^{\circ} \mathrm{C}$ for a final concentration in a $210-\mathrm{L}$ gas-tight chamber of $700 \mathrm{~nL} \cdot \mathrm{L}^{-1}$ (ppb)], or DI water for $4 \mathrm{~h}$. Subsequently, cut stems were transferred to vases filled with DI water, placed in a 210 -L gastight chambers, and immediately treated with exogenous ethylene at 0 or $1 \mu \mathrm{L} \cdot \mathrm{L}^{-1}$ for $16 \mathrm{~h}$.

General Procedures. During vase life evaluation, stems were held at $40 \%$ to $60 \%$ relative humidity, $20 \pm$ $2{ }^{\circ} \mathrm{C}$, and a 12 -h photoperiod at 20 to $40 \mu \mathrm{mol} \cdot \mathrm{m}^{-2} \cdot \mathrm{s}^{-1}$ from cool white fluorescent lamps. Unless otherwise indicated, DI water at $22^{\circ} \mathrm{C}$ was used in all experiments as a vase solution. Retail vase life termination was evaluated for linaria, poppy, and trachelium and was defined as the first day a visible change in the flower or inflorescence develops that would make the stems unmarketable by retailers. Consumer vase life was evaluated in all experiments. Vase life termination characteristics for each species are described in Table 1.

Statistical analysis. All experiments were arranged in a completely randomized design, with 12 to 15 replications of a single stem per floral vase. Each experiment was repeated once. Analysis of variance was performed for all experiments, and factorial design and mixed models were applied when two factors at various levels were studied. Means separation was accomplished by least significant difference using SAS (version 9.1; SAS Institute, Cary, NC).

\section{Results}

Control solutions. DI supplemented with 8-HQC extended linaria retail and consumer vase life, especially if adjusted to $\mathrm{pH} 3.5$ (Table 2). Consumer vase life of rudbeckia, trachelium, and 'Sun Gold' zinnia was longer when stems were held in unamended DI or tap water. Solutions had no effect on the consumer vase life of cut lupine, dahlia, poppy, and 'Benary's Giant Scarlet' zinnia or the retail vase life for poppy and trachelium stems (data not presented).

Sucrose AND VASE SUBSTRATE. The addition of $2 \%$ or $4 \%$ sucrose to vase water extended consumer vase

Table 2. Retail and consumer vase life of cut linaria, rudbeckia, trachelium, and zinnia stems held in deionized (DI) water, with or without $200 \mathrm{mg} \cdot \mathrm{L}^{-1}(\mathrm{ppm})$ 8-hydroxyquinoline citrate $(8-\mathrm{HQC})$, and non-or -adjusted pH or tap water or tap water with 8 -HQC and adjusted $\mathrm{pH}$ postharvest room conditions: $40 \%$ to $60 \%$ relative humidity, $20 \pm 2{ }^{\circ} \mathrm{C}\left(68.0 \pm 3.6^{\circ} \mathrm{F}\right)$, and 12-h photoperiod at 20 to $40 \mu \mathrm{mol} \cdot \mathrm{m}^{-2} \cdot \mathrm{s}^{-1}$. Means are an average of $15 \mathrm{stems}$.

\begin{tabular}{|c|c|c|c|c|c|}
\hline \multirow[b]{3}{*}{ Solutions } & \multicolumn{2}{|c|}{ 'Lace Violet' linaria } & \multirow{2}{*}{$\begin{array}{c}\begin{array}{c}\text { 'Indian Summer' } \\
\text { rudbeckia }\end{array} \\
\text { Consumer }\end{array}$} & \multirow{2}{*}{$\begin{array}{c}\begin{array}{c}\text { 'Jemmy Royal } \\
\text { Purple' trachelium }\end{array} \\
\text { Consumer }\end{array}$} & \multirow{2}{*}{$\frac{\text { 'Sun Gold' zinnia }}{\text { Consumer }}$} \\
\hline & Retail & Consumer & & & \\
\hline & \multicolumn{5}{|c|}{ Vase life (d) } \\
\hline DI water & $2.8 \mathrm{~b}^{\mathrm{z}}$ & $5.3 \mathrm{c}$ & $33.1 \mathrm{a}$ & $9.5 \mathrm{a}$ & $14.9 \mathrm{a}$ \\
\hline DI water $\mathrm{pH} 3.5$ & $2.9 \mathrm{~b}$ & $5.5 \mathrm{c}$ & $-^{\mathrm{y}}$ & - & - \\
\hline DI water + 8-HQC & $6.7 \mathrm{a}$ & $8.4 \mathrm{~b}$ & $20.7 \mathrm{~b}$ & $8.6 \mathrm{ab}$ & $9.9 \mathrm{~b}$ \\
\hline Tap water + 8-HQC pH 3.5 & - & - & - & $8.5 \mathrm{~b}$ & $11.3 \mathrm{ab}$ \\
\hline Significance & $* * *$ & $* * *$ & ** & $* *$ & * \\
\hline
\end{tabular}

${ }^{2}$ Within columns, means followed by the same letter are not significantly different according to least significant difference test at $P \leq 0.05$.

yTreatment not conducted.

${ }^{*},{ }^{* *},{ }^{* *}$ Significant at $P \leq 0.05,0.01$, or 0.001 , respectively 
life of linaria with or without floral foam (Table 3 ). The consumer vase life of trachelium increased significantly $(P<0.05)$ in a holding solution containing $2 \%$ sucrose with or without floral foam. In zinnias, the longest consumer vase life was recorded when cut stems were held in 2\% sucrose without foam for 'Benary's Giant Scarlet'. 'Sun Gold' zinnia lasted longest with just DI water or with sucrose at $4 \%$ and no foam. Floral foam or sucrose had no effect on the consumer vase life of dahlia, lupine, rudbeckia, and poppy or on the retail vase life of linaria and trachelium (data not presented).

SuCrose PUlse. Linaria retail and consumer vase lives were extended by pulsing in $10 \%$ or $20 \%$ sugar concentration, but no differences were observed between concentrations (Table 4). Sucrose pulse at any concentration significantly reduced $(P<0.05)$ the consumer vase life of rudbeckia. Trachelium retail and consumer vase life decreased when pulsed with $20 \%$ sucrose. Consumer vase life of 'Benary's Giant Scarlet' zinnia was significantly extended by a $10 \%$ sucrose pulse compared with the control. Sucrose pulse had no effect on retail and consumer vase lives for poppy or consumer vase life of dahlia, lupine, and 'Sun Gold' zinnia (data not presented).

CommerCiAL PRESERVATIVES. Cut linaria stems showed the longest retail and consumer vase lives when a commercial holding solution (FLP or CP2) was used (Table 5). The hydrator solution itself did not improve the vase life. For trachelium, consumer vase life was longest when cut stems were held in the DI/CP2 hydrator/ holding solution combination; the vase life of the FL100/DI and DI/ DI treatments was shorter than the DI/CP2 treatment but longer than the remaining treatment combinations. Retail vase life of trachelium $(9.0 \mathrm{~d})$ and consumer vase life of rudbeckia (32.4 d) and 'Benary's Giant Scarlet' (19.2 d) and 'Sun Gold' (18.8 d) zinnias were unaffected by the commercial preservatives (data not presented). For dahlia, lupine, and poppy, FLP commercial holding preservative, without previous hydrator treatment, significantly improved $(P<0.05)$ the consumer vase life (Table 6).

Cold storage. Cold storage for I week significantly decreased the vase life of cut dahlia stems, and stem rehydration was not possible after 2 weeks (Table 7 ). Retail vase life of nonstored cut linaria stems was similar to that of stems stored for 2 or 3 weeks, and no differences were observed between wet or dry storage. Wet storage for 1 or 2 weeks maintained the consumer longevity of cut lupine stems compared with unstored stems. Consumer vase life of poppy was similar to unstored controls after 1 week in wet or dry storage. For trachelium, the retail and consumer

Table 3. Consumer vase life of cut linaria, trachelium, and zinnia stems held in sucrose solutions with or without floral foam substrate. Postharvest room conditions: $40 \%$ to $60 \%$ relative humidity, $20 \pm 2{ }^{\circ} \mathrm{C}\left(68.0 \pm 3.6{ }^{\circ} \mathrm{F}\right)$, and 12 -h photoperiod at 20 to $40 \mathrm{mmol} \cdot \mathrm{m}^{-2} \cdot \mathrm{s}^{-1}$. Means are an average of $15 \mathrm{stems}$.

\begin{tabular}{|c|c|c|c|c|c|}
\hline \multicolumn{2}{|l|}{ Treatments } & $\frac{\text { 'Lace Violet' linaria }}{\text { Consumer }}$ & $\begin{array}{c}\begin{array}{c}\text { 'Jemmy Royal' } \\
\text { Purple' trachelium }\end{array} \\
\text { Consumer }\end{array}$ & $\begin{array}{l}\text { 'Benary's Giant } \\
\text { Scarlet' zinnia } \\
\text { Consumer }\end{array}$ & $\frac{\text { 'Sun Gold' zinnia }}{\text { Consumer }}$ \\
\hline Substrate & Sucrose (\%) & \multicolumn{4}{|c|}{ Vase life (d) } \\
\hline \multirow[t]{3}{*}{ None } & 0 & $9.1 c^{z}$ & $13.2 \mathrm{~cd}$ & $11.3 \mathrm{bc}$ & $15.3 \mathrm{a}$ \\
\hline & 2 & $17.5 \mathrm{a}$ & $17.7 \mathrm{ab}$ & $16.1 \mathrm{a}$ & $10.5 \mathrm{~b}$ \\
\hline & 4 & $13.7 \mathrm{~b}$ & $15.3 \mathrm{bc}$ & $10.1 \mathrm{c}$ & $14.9 \mathrm{a}$ \\
\hline & 4 & $19.2 \mathrm{a}$ & $15.9 \mathrm{bc}$ & $11.5 \mathrm{bc}$ & $7.9 \mathrm{~b}$ \\
\hline \multicolumn{6}{|l|}{ Significance } \\
\hline Substrate & & * & NS & * & $* * *$ \\
\hline Sucrose & & ** & ** & $* * *$ & $* *$ \\
\hline $\mathrm{Sb} \times \mathrm{Sc}$ & & ** & * & $* *$ & ** \\
\hline
\end{tabular}

${ }^{2}$ Within columns, means followed by the same letter are not significantly different according to least significant difference test at $P \leq 0.05$.

NS, ${ }^{*}, * * * *$ Not significant or significant at $P \leq 0.05,0.01$, or 0.001 , respectively.

Table 4. Retail and consumer vase life of cut linaria, trachelium, rudbeckia, and zinnia stems pulsed in $0 \%$, $10 \%$, or $20 \%$ sucrose solutions for $24 \mathrm{~h}$. Postharvest room conditions: $40 \%$ to $60 \%$ relative humidity, $20 \pm 2{ }^{\circ} \mathrm{C}\left(68.0 \pm 3.6{ }^{\circ} \mathrm{F}\right)$, and 12 -h photoperiod at 20 to $40 \mu \mathrm{mol} \cdot \mathrm{m}^{-2} \cdot \mathrm{s}^{-1}$. Means are an average of $15 \mathrm{stems}$.

\begin{tabular}{|c|c|c|c|c|c|c|}
\hline \multirow[b]{3}{*}{ Sucrose (\%) } & \multicolumn{2}{|c|}{ 'Lace Violet' linaria } & \multicolumn{2}{|c|}{$\begin{array}{c}\text { 'Jemmy Royal Purple' } \\
\text { trachelium }\end{array}$} & \multirow{2}{*}{$\begin{array}{c}\text { 'Indian Summer' } \\
\text { rudbeckia } \\
\text { Consumer }\end{array}$} & \multirow{2}{*}{$\begin{array}{l}\text { 'Benary's Giant } \\
\text { Scarlet' zinnia } \\
\text { Consumer }\end{array}$} \\
\hline & Retail & Consumer & Retail & Consumer & & \\
\hline & & & & Vase life $(d)$ & & \\
\hline 0 & $4.0 \mathrm{~b}^{\mathrm{z}}$ & $5.1 \mathrm{~b}$ & $11.3 \mathrm{a}$ & $19.0 \mathrm{a}$ & $37.1 \mathrm{a}$ & $8.9 \mathrm{~b}$ \\
\hline 10 & $6.1 \mathrm{a}$ & $8.9 \mathrm{a}$ & $12.7 \mathrm{a}$ & $18.6 \mathrm{a}$ & $8.7 \mathrm{~b}$ & $13.7 \mathrm{a}$ \\
\hline 20 & $6.9 \mathrm{a}$ & $9.2 \mathrm{a}$ & $6.9 \mathrm{~b}$ & $2.1 \mathrm{~b}$ & $6.9 \mathrm{~b}$ & $10.1 \mathrm{ab}$ \\
\hline
\end{tabular}

${ }^{2}$ Within columns, means followed by the same letter are not significantly different according to least significant difference test at $P \leq 0.05$.

$* *$ *** Significant at $P \leq 0.01$ or 0.001 , respectively. 
Table 5. Retail and consumer vase life of cut linaria and trachelium stems pulsed in Chrysal Professional 1 Hydrating Solution $^{\mathrm{z}}$ (CP1), Floralife Hydraflor 100y (FL100), or deionized water (DI) and held in Chrysal Professional 2 Processing solution $^{\mathrm{z}}$ (CP2), Floralife Professionaly ${ }^{\mathrm{y}}$ (FLP), or deionized water (DI) as holding solutions. Postharvest room conditions: $40 \%$ to $60 \%$ relative humidity, $20 \pm 2{ }^{\circ} \mathrm{C}\left(68.0 \pm 3.6^{\circ} \mathrm{F}\right)$, and 12 -h photoperiod at 20 to $40 \mu \mathrm{mol} \cdot \mathrm{m}^{-2} \cdot \mathrm{s}^{-1}$. Means are an average of 11 to 15 stems.

\begin{tabular}{|c|c|c|c|c|}
\hline \multirow[b]{2}{*}{ Treatments } & & \multicolumn{2}{|c|}{ 'Lace Violet' linaria } & \multirow{2}{*}{$\begin{array}{c}\begin{array}{c}\text { 'Jemmy Royal } \\
\text { Purple' trachelium }\end{array} \\
\text { Consumer }\end{array}$} \\
\hline & & Retail & Consumer & \\
\hline Hydrator & Holding & \multicolumn{3}{|c|}{ Vase life $(\mathrm{d})$} \\
\hline \multirow[t]{3}{*}{ DI } & $\mathrm{CP} 2$ & $8.3 \mathrm{a}^{\mathrm{x}}$ & $9.8 \mathrm{a}$ & $17.5 \mathrm{a}$ \\
\hline & FLP & $9.0 \mathrm{a}$ & $11.8 \mathrm{a}$ & $11.2 \mathrm{c}$ \\
\hline & DI & $5.3 \mathrm{~b}$ & $5.6 \mathrm{~b}$ & $15.1 \mathrm{~b}$ \\
\hline \multirow[t]{2}{*}{$\mathrm{CPl}$} & $\mathrm{CP} 2$ & $9.1 \mathrm{a}$ & $10.5 \mathrm{a}$ & $11.0 \mathrm{c}$ \\
\hline & DI & $5.2 \mathrm{~b}$ & $5.2 \mathrm{~b}$ & $10.9 \mathrm{c}$ \\
\hline \multirow[t]{2}{*}{ FL100 } & FLP & $9.5 \mathrm{a}$ & $12.9 \mathrm{a}$ & $10.9 \mathrm{c}$ \\
\hline & DI & $5.4 \mathrm{~b}$ & $5.4 \mathrm{~b}$ & $15.1 \mathrm{~b}$ \\
\hline Significance & & $* * *$ & *** & $* * *$ \\
\hline
\end{tabular}

${ }^{\mathrm{z}}$ Bendien, Naarden, The Netherlands.

'Floralife ${ }^{\circledR}$, Walterboro, SC.

${ }^{x}$ Within columns, means followed by the same letter are not significantly different according to least significant difference test at $P \leq 0.05$.

$* * *$ Significant at $P \leq 0.001$.

Table 6. Consumer vase life of cut dahlia, lupine, and poppy stems after holding in Chrysal Professional 2 Processing $^{\mathrm{z}}$ (CP2), Floralife Professionaly (FLP), or deionized water (DI) solutions. Postharvest room conditions: $40 \%$ to $60 \%$ relative humidity, $20 \pm 2{ }^{\circ} \mathrm{C}\left(68.0 \pm 3.6^{\circ} \mathrm{F}\right)$, and 12 -h photoperiod at 20 to $40 \mu \mathrm{mol} \cdot \mathrm{m}^{-2} \cdot \mathrm{s}^{-1}$. Means are an average of 12 to $15 \mathrm{stems}$.

\begin{tabular}{|c|c|c|c|}
\hline \multirow{2}{*}{$\begin{array}{l}\text { Commercial holding } \\
\text { preservative }\end{array}$} & $\begin{array}{c}\text { 'Karma Thalia' } \\
\text { dahlia }\end{array}$ & 'Sunrise' lupine & 'Temptress' poppy \\
\hline & \multicolumn{3}{|c|}{ Consumer vase life $(d)$} \\
\hline DI & $8.6 b^{x}$ & $8.6 \mathrm{~b}$ & $5.5 \mathrm{~b}$ \\
\hline $\mathrm{CP} 2$ & $10.1 \mathrm{ab}$ & $9.9 \mathrm{ab}$ & $7.9 \mathrm{a}$ \\
\hline FLP & $10.8 \mathrm{a}$ & $12.2 \mathrm{a}$ & $7.6 \mathrm{a}$ \\
\hline Significance & ** & $* * *$ & $* * *$ \\
\hline
\end{tabular}

vase lives decreased significantly as the storage was prolonged, regardless of the storage condition. In addition, rehydration did not occur in lupine, poppy, and trachelium after dry or wet storage for 3 weeks. Cut zinnia stems did not rehydrate after any length of cold storage (data not presented); vase life of nonstored stems averaged $16.4 \mathrm{~d}$ for 'Benary's Giant Scarlet' and $11.4 \mathrm{~d}$ for 'Sun Gold'. Up to 3 weeks of cold storage did not affect consumer vase life of linaria (4.6 d) and rudbeckia ( $34.3 \mathrm{~d}$ ) or the retail vase life of poppy $(3.7 \mathrm{~d})$ (data not presented).

Ethylene Sensitivity. Consumer vase life of cut lupine stems was decreased due to floret abscission solution is often debated (van Meeteren et al., 2000). Most of the specialty cut flowers tested in this study can be held in tap or DI water without altering their vase lives (Table 2). An exception was cut linaria stems in which DI supplemented with 8HQC with adjusted or nonadjusted $\mathrm{pH}$ produced the longest retail vase life. It was also necessary to adjust $\mathrm{pH}$ and add 8-HQC to the holding water to significantly extend the consumer vase life of linaria. DI or tap water similarly reduced the retail and consumer lives of linaria. Thus, the addition of the germicide 8-HQC was crucial to increase the vase life in linaria. With cut roses (Rosa hybrida), 8-HQC and low $\mathrm{pH}$ avoided vascular blockage in stems due to the reduction of bacterial population (van Doorn and Perik, 1990). Furthermore, fresh weight was improved in carnation (Dianthus caryophyllus) and alstroemeria (Alstroemeria hybrids) (Knee, 2000) after the incorporation of 8 -HQC in the vase solution. In general, germicides enhance fresh weight by improving solution uptake (Jones and Hill, 1993).

However, consumer vase life in rudbeckia and 'Sun Gold' zinnia decreased significantly when 8 -HQC was added to the vase water. The addition of 8-HQC to the holding water caused phytotoxicity in 'Fantasia' statice (Limonium hybrids) (Doi and Reid, 1995). Germicide effect can vary considerably among species and cultivars (Jones and Hill, 1993). For example, Stimart et al. (1983) noted that 8 -HQC increased zinnia fresh weight.

Floral foam was designed to absorb water evenly and to hold stems in place for floral designs, but water release depends on the density of foam. Floral foam might restrict water uptake, as reported for cut poinsettia (Euphorbia pulcherrima) stems (Dole et al., 2004), therefore shortening vase life. In this study, while the use of floral foam reduced vase life of both zinnia cultivars at $0 \%$ or $2 \%$ sucrose, it did not affect the vase lives of most cut flowers compared with treatments without foam (Table 3). Big bend bluebonnet inflorescences showed similar vase life $(10 \mathrm{~d})$ when set in water or floral foam (Davis et al., 1995). Sucrose supplementation of $2 \%$ was sufficient to improve vase life in linaria, trachelium, and 'Benary's 
Table 7. Retail and consumer vase life of dahlia, linaria, lupine, poppy and trachelium stems after dry or wet storage for 1,2 , or 3 weeks at $2^{\circ} \mathrm{C}\left(35.6^{\circ} \mathrm{F}\right)$. Postharvest room conditions: $40 \%$ to $60 \%$ relative humidity, $20 \pm 2{ }^{\circ} \mathrm{C}\left(68.0 \pm 3.6^{\circ} \mathrm{F}\right)$, and 12-h photoperiod at 20 to $40 \mu \mathrm{mol} \cdot \mathrm{m}^{-2} \cdot \mathrm{s}^{-1}$. Means are an average of 12 to $15 \mathrm{stems}$.

\begin{tabular}{|c|c|c|c|c|c|c|c|}
\hline & \multirow{2}{*}{$\begin{array}{c}\text { 'Karma Thalia' } \\
\text { dahlia } \\
\text { Consumer }\end{array}$} & \multirow{2}{*}{$\begin{array}{c}\text { 'Lace Violet' } \\
\text { linaria } \\
\text { Retail }\end{array}$} & \multirow{2}{*}{$\begin{array}{c}\begin{array}{c}\text { 'Sunrise' } \\
\text { lupine }\end{array} \\
\text { Consumer }\end{array}$} & \multirow{2}{*}{$\begin{array}{c}\text { 'Temptress' } \\
\text { poppy } \\
\text { Consumer }\end{array}$} & \multicolumn{2}{|c|}{$\begin{array}{c}\text { 'Jemmy Royal } \\
\text { Purple' trachelium }\end{array}$} \\
\hline & & & & & & Retail & Consumer \\
\hline \multicolumn{2}{|c|}{ Treatments } & & \multicolumn{2}{|c|}{ Vase life (d) } & & & \\
\hline 0 & 0 & $8.5 \mathrm{a}^{\mathrm{z}}$ & $4.2 \mathrm{a}$ & $11.5 \mathrm{a}$ & $6.6 \mathrm{a}$ & $12.3 \mathrm{a}$ & $14.3 \mathrm{a}$ \\
\hline \multirow[t]{2}{*}{1} & Wet & $6.7 \mathrm{~b}$ & $2.6 \mathrm{~b}$ & $8.5 \mathrm{ab}$ & $6.6 \mathrm{a}$ & $7.7 \mathrm{~b}$ & $9.0 \mathrm{~b}$ \\
\hline & Dry & $6.6 \mathrm{~b}$ & $2.5 \mathrm{~b}$ & $7.2 \mathrm{~b}$ & $6.0 \mathrm{a}$ & $6.8 \mathrm{~b}$ & $9.1 \mathrm{~b}$ \\
\hline \multirow[t]{2}{*}{3} & Wet & - & $3.1 \mathrm{ab}$ & - & - & - & - \\
\hline & Dry & & $4.2 \mathrm{a}$ & - & - & - & - \\
\hline \multicolumn{8}{|c|}{ Significance } \\
\hline & & - & ** & NS & ** & ** & * \\
\hline & n $(\mathrm{C})$ & NS & NS & * & NS & NS & NS \\
\hline
\end{tabular}

${ }^{2}$ Within columns, means followed by the same letter are not significantly different according to least significant difference test at $P \leq 0.05$.

y Flowers did not rehydrate after storage.

Ns, ${ }^{*},{ }^{*}$ Not siginificant or significant at $P \leq 0.05$ or 0.01 , respectively.

Table 8. Retail and consumer vase life of cut lupine and trachelium after treatment with $700 \mathrm{~nL} \cdot \mathrm{L}^{-1}$ (ppb) 1-methylcyclopropene (MCP) or $0.2 \mathrm{~mm}$ silver thiosulfate (STS) before application of exogenous ethylene at 0 or $1 \mu \mathrm{L} \cdot \mathrm{L}^{-1}$ for $16 \mathrm{~h}$. Postharvest room conditions: $40 \%$ to $60 \%$ relative humidity, $20 \pm 2{ }^{\circ} \mathrm{C}$ $\left(68.0 \pm 3.6^{\circ} \mathrm{F}\right)$, and $12-\mathrm{h}$ photoperiod at 20 to $40 \mu \mathrm{mol} \cdot \mathrm{m}^{-2} \cdot \mathrm{s}^{-1}$. Means are an average of 7 to 15 stems.

\begin{tabular}{|c|c|c|c|c|}
\hline \multicolumn{2}{|l|}{ Treatments } & \multirow{2}{*}{$\frac{\text { 'Sunrise' lupine }}{\text { Consumer }}$} & \multicolumn{2}{|c|}{$\begin{array}{l}\text { 'Jemmy Royal } \\
\text { Purple' trachelium }\end{array}$} \\
\hline \multirow{2}{*}{$\begin{array}{l}\text { Antiethylene } \\
\text { treatment }\end{array}$} & \multirow[b]{2}{*}{ Ethylene $\left(\mu \mathrm{L} \cdot \mathrm{L}^{-1}\right)$} & & Retail & Consumer \\
\hline & & \multicolumn{3}{|c|}{ Vase life $(\mathrm{d})$} \\
\hline \multirow[t]{2}{*}{ None } & 0 & $8.0 \mathrm{ab}^{\mathrm{z}}$ & $7.7 \mathrm{ab}$ & $8.1 \mathrm{a}$ \\
\hline & 1 & $2.0 \mathrm{c}$ & $2.5 \mathrm{c}$ & $2.5 \mathrm{~b}$ \\
\hline \multirow[t]{2}{*}{ MCP } & 0 & $9.9 \mathrm{a}$ & $8.3 \mathrm{ab}$ & $9.1 \mathrm{a}$ \\
\hline & 1 & $8.3 \mathrm{ab}$ & $7.5 \mathrm{ab}$ & $8.5 \mathrm{a}$ \\
\hline \multirow[t]{2}{*}{ STS } & 0 & $10.1 \mathrm{a}$ & $8.0 \mathrm{ab}$ & $8.8 \mathrm{a}$ \\
\hline & 1 & $6.3 \mathrm{~b}$ & $7.2 \mathrm{~b}$ & $8.6 \mathrm{a}$ \\
\hline \multicolumn{5}{|l|}{ Significance } \\
\hline \multicolumn{2}{|c|}{ Anti-ethylene (A) } & $* * *$ & $* * *$ & $* * *$ \\
\hline \multicolumn{2}{|l|}{ Ethylene (E) } & $* * *$ & $* * *$ & $* * *$ \\
\hline \multicolumn{2}{|l|}{$\mathrm{A} \times \mathrm{E}$} & $* * *$ & $* * *$ & $* * *$ \\
\hline
\end{tabular}

${ }^{2}$ Within columns, means followed by the same letter are not significantly different according to least significant difference test at $P \leq 0.05$.

$* * *$ Significant at $P \leq 0.001$.

Giant Scarlet' zinnia. The addition of $0 \%$ or $4 \%$ sucrose induced the longest vase life of 'Sun Gold' zinnia. Sucrose is very useful in extending vase life by helping water balance and turgidity and by providing a carbohydrate source (Nair et al., 2003).

Only linaria and 'Benary's Giant Scarlet' zinnia showed a positive response to sucrose pulses at $10 \%$ or $20 \%$ (Table 4). Similarly, high sucrose in pulsing or holding solution enhanced sugar concentration in cut lisianthus (Eustoma grandiflorum) stems (Cho et al., 2001). High
(20\%) sucrose pretreatment increased water uptake of cut gladioli after the stems were transferred into water (Mayak et al., 1973). Also, sucrose treatments delayed the onset of ethylene production and responsiveness in 'White Sim' carnation petals (Verlinden and Vicente Garcia, 2004). In contrast, a $20 \%$ sucrose pulse decreased the consumer and retail vase lives of trachelium, and a $10 \%$ and $20 \%$ sucrose pulse reduced the vase life of rudbeckia. Premature drying and yellowing were observed in lisianthus (Cho et al., 2001), and leaf browning occurred in kangaroo paw (Anigozanthos hybrids) (Teagle et al., 1991 ) after pulsing in $20 \%$ sucrose.

The fact that commercial hydrators did not enhance retail or consumer vase life of any species tested confirms that cut stems need treatments other than hydration to maintain quality and to enhance postharvest life (Tables 5 and 6). Commercial holding agents not only provided ingredients to hydrate cut stems, but also carbohydrates to extend postharvest quality and longevity. In many species, commercial holding solutions increase vase life (Sacalis, 1993). For example, vase life, flower size, and number of open flowers increased in brazilian snapdragon (Otacanthus coeruleus) with the addition of Chrysal Universal to the vase solution (Geertsen, 1990).

The inconsistent effectiveness of the preservatives observed among the species of this study has been reported within cultivars of the same species (Heuser and Evensen, 1986; Maclean and Rasmussen, 1980). Consequently, additional preservative sources, doses, and developmental stages of cut stems must be also studied.

In this study, dry or wet storage at a low temperature had a similar effect on vase life of all cut flowers, except for lupine, where wet storage was slightly more beneficial than dry storage (Table 7). Similarly, dry or wet storage for species-specific durations at temperature between 0 and $10{ }^{\circ} \mathrm{C}$ did not affect vase life of 
carnation, daffodil (Narcissus psendonarcissus), iris (Iris hollandica), killian daisy (Chrysanthemum maximum), paperwhite narcissus (Narcissus tazetta), rose, or tulip (Tulipa gesneriana) (Cevallos and Reid, 2001). Linaria and rudbeckia could be stored for 3 weeks without significant loss of vase life. Longevity of cut dahlia and trachelium stems decreased significantly with the first week of storage. Cut poppy and lupine stems tolerated cold storage for a maximum of 2 weeks. In a previous report, STS-preconditioned cut big bend bluebonnet inflorescences, stored wet at $5{ }^{\circ} \mathrm{C}$ for $3 \mathrm{~d}$, had a vase life similar to nonstored stems ( 9 d) without quality loss (Davis et al., 1995).

Zinnias should not be cold stored at $2{ }^{\circ} \mathrm{C}$ because both cultivars lost petal and foliar turgidity, did not rehydrate, and exhibited cold damage regardless of being stored dry or wet. Cold storing 'Sun Gold' flowers resulted in flower petal browning and stem collapse, while 'Benary's Giant Scarlet' showed yellow patches on the red petals and stem collapse. The yellow patches on the petals of 'Benary's Giant Scarlet' were observed 1 to $2 \mathrm{~d}$ after cold storage. Zinnia producers have also noted that $\mathrm{l}$ to $3 \mathrm{~d}$ of cold storage below $5{ }^{\circ} \mathrm{C}$ reduced vase life and sometimes produced petal browning (Arnosky and
Arnosky, 2003; E. Hitt, personal communication).

Ethylene application only shortened the vase life of lupine and trachelium; hence, the incorporation of antiethylene-binding chemicals extended their vase lives (Table 8). MCP and STS were similarly effective in extending cut flower vase life of lupine and trachelium. In big bend bluebonnet, MCP also extended the vase life longevity by about $2 \mathrm{~d}$ (Valenzuela-Vasquez et al., 2007).

In summary, most of the species, 'Karma Thalia' dahlia, 'Indian Summer' rudbeckia, 'Sunrise' lupine, 'Jemmy Royal Purple' trachelium, and zinnia cultivars 'Benary's Giant Scarlet' and 'Sun Gold', have excellent commercial potential, as they had a consumer vase life that exceeded $7 \mathrm{~d}$ when stems were not treated or stored. A summary table showing the responses of each species and cultivar to the treatments is included (Table 9). Of note, rudbeckia was the longest-lived species, lasting at least $20 \mathrm{~d}$. The focus on nonstored treatments is important because many specialty cut flower growers direct-retail their flowers, and specialty cut flower growers are an increasingly important segment of the cut flower industry in the United States.

In contrast, the vase life of 'Temptress' poppy was only 5.5 to
$6.6 \mathrm{~d}$ for unstored, untreated stems. However, the use of commercial holding solutions increased vase life to at least $9 \mathrm{~d}$, which would allow it to be used commercially.

The commercial potential of 'Lace Violet' linaria may be restricted due to a vase life of less than $7 \mathrm{~d}$ in some experiments and due to a wide variation in vase life from a low of 4.6 $\mathrm{d}$ to a high of $9.1 \mathrm{~d}$ in the nonstored DI water treatments. Such variability would reduce confidence in the species by retailers, limiting use of the linaria to events where only a $5 \mathrm{~d}$ or shorter vase life is necessary. Trachelium and 'Benary's Giant Scarlet' zinnia similarly exhibited a wide variation in vase life; however, the minimum vase life was greater than $7 \mathrm{~d}$. Variation in vase life needs to be documented for new cut flower species to ensure that growers and retailers are aware of the problem.

In this study, the variation in vase life for a specific species from experiment to experiment may have been due to preharvest factors of light level, production temperature, water availability, and humidity (Adachi et al., 1999; de Barrera and Arenas, 1999; van Gorsel, 1993). For example, van Gorsel (1993) noted that the vase life of bouvardia (Bouvardia hybrid) varied from $9 \mathrm{~d}$ during the early spring to $18 \mathrm{~d}$ during the fall and that season had a more pronounced effect on vase

Table 9. Postharvest performance of cut dahlia, linaria, lupine, poppy, rudbeckia, trachelium, and zinnia stems subjected to different treatments, which increased vase life $(+)$, reduced vase life $(-)$, or had no effect (NE) compared with the control treatments. Sucrose and floral foam = stems pulsed in $\mathbf{0 \%}, \mathbf{1 0} \%$, or $20 \%$ sucrose solutions for 24 h (Pulse) or subjected to $0 \%$, $\mathbf{2 \%}$, or $\mathbf{4 \%}$ in the vase solution (Vase water) with or without floral foam substrate. Commercial preservatives $=$ stems pulsed in hydrating solution (Chrysal Professional 1 Hydrating Solution ${ }^{\mathrm{z}}$, Floralife Hydraflor 100 ${ }^{\mathrm{y}}$, or deionized water) and held in a

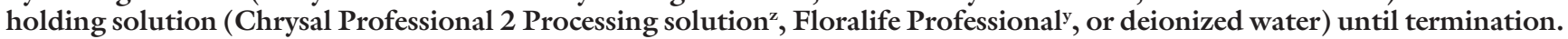
Cold storage $=$ stems stored dry or wet for 1,2 , or 3 weeks at $2^{\circ} \mathrm{C}\left(35.6{ }^{\circ} \mathrm{F}\right)$. Ethylene sensitivity $=$ stems treated with either $700 \mathrm{~nL} \cdot \mathrm{L}^{-1}$ (ppb) 1 -methylcyclopropene (MCP) or $0.2 \mathrm{~mm}$ silver thiosulfate (STS) before application of exogenous ethylene (Exog.) at 0 or $1 \mu \mathrm{L} \cdot \mathrm{L}^{-1}(\mathrm{ppm})$ for $16 \mathrm{~h}$. Postharvest room conditions were $40 \%$ to $60 \%$ relative humidity, $20 \pm 2{ }^{\circ} \mathrm{C}(68.0 \pm$ $\left.3.6^{\circ} \mathrm{F}\right)$, and $12-\mathrm{h}$ photoperiod at 20 to $40 \mu \mathrm{mol} \cdot \mathrm{m}^{-2} \cdot \mathrm{s}^{-1}$.

\begin{tabular}{|c|c|c|c|c|c|c|c|c|c|c|c|}
\hline \multirow[b]{3}{*}{ Cut flowers } & \multicolumn{2}{|c|}{ Sucrose } & \multirow{3}{*}{$\begin{array}{c}\text { Floral } \\
\text { foam }\end{array}$} & \multirow{2}{*}{\multicolumn{2}{|c|}{$\begin{array}{l}\text { Commercial } \\
\text { preservatives }\end{array}$}} & \multirow{2}{*}{\multicolumn{3}{|c|}{ Cold storage }} & \multirow{2}{*}{\multicolumn{3}{|c|}{ Ethylene sensitivity }} \\
\hline & \multirow[b]{2}{*}{ Pulse } & \multirow{2}{*}{$\begin{array}{c}\text { Vase } \\
\text { water }\end{array}$} & & & & & & & & & \\
\hline & & & & Hydrator & Holding & $\overline{\text { Dry }}$ & Wet & Week $^{\mathrm{x}}$ & Exog. & STS & MCP \\
\hline 'Lace Violet' linaria & + & + & $\mathrm{NE}$ & $\mathrm{NE}$ & + & $\mathrm{NE}$ & $\mathrm{NE}$ & 3 & $\mathrm{NE}$ & $\mathrm{NE}$ & $\mathrm{NE}$ \\
\hline 'Sunrise' lupine & $\mathrm{NE}$ & $\mathrm{NE}$ & $\mathrm{NE}$ & $\mathrm{NE}$ & + & $\mathrm{NE}$ & $\mathrm{NE}$ & 1 & - & + & + \\
\hline 'Temptress' poppy & $\mathrm{NE}$ & $\mathrm{NE}$ & $\mathrm{NE}$ & $\mathrm{NE}$ & + & $\mathrm{NE}$ & $\mathrm{NE}$ & 1 & $\mathrm{NE}$ & $\mathrm{NE}$ & $\mathrm{NE}$ \\
\hline 'Benary's Giant Scarlet' zinnia & + & + & - & $\mathrm{NE}$ & $\mathrm{NE}$ & $\mathrm{NE}$ & $\mathrm{NE}$ & 0 & $\mathrm{NE}$ & $\mathrm{NE}$ & $\mathrm{NE}$ \\
\hline 'Sun Gold' zinnia & $\mathrm{NE}$ & + & - & $\mathrm{NE}$ & $\mathrm{NE}$ & $\mathrm{NE}$ & $\mathrm{NE}$ & 0 & $\mathrm{NE}$ & $\mathrm{NE}$ & $\mathrm{NE}$ \\
\hline
\end{tabular}

${ }^{z}$ Bendien, Naarden, The Netherlands.

Floralife ${ }^{\circledR}$, Walterboro, SC.

${ }^{x}$ Maximum number of weeks stems could be stored without reducing vase life. 
life than production temperature. Studies have linked vase life to commercial greenhouse production conditions and noted that high light and low relative humidity were correlated with increased vase life (Marissen, 2005; Slootweg, 2005). In our studies, all experiments for each species were completed within 1 month, but there may have been sufficient variation in growing conditions during that time to influence vase life. Slootweg (2005) noted that conditions in the last 2 weeks before harvest may be most critical.

\section{Literature cited}

Adachi, M., S. Kawabata, and R. Sakiyama. 1999. Changes in carbohydrate content in cut chrysanthemums (Dendranthema $\times$ grandiflorum (Ramat.) Kitamura 'Shuho-no-chikara') plants during flower opening and senescence at different temperatures. J. Jpn. Soc. Hort. Sci. 68: 228-235.

Arnosky, P. and F. Arnosky. 2003. Specialty cut flowers: Mysteries of zinnia postharvest revealed. Growing for Market 12:15-18.

Cevallos, J.C. and M.S. Reid. 2001. Effect of dry and wet storage at different temperatures on the vase life of cut flowers. HortTechnology 11:199-202.

Cho, M.S., F.G. Celikel, L. Dodge, and M.S. Reid. 2001. Sucrose enhances the postharvest quality of cut flowers of Eustoma gradiflorum (Raf.). Shinn. Acta Hort. 543:305-315.

Davis, T.D., W.A. Mackay, and N. Sankhla. 1995. Postharvest characteristics of cut inflorescences of Lupinus havardii. HortTechnology 5:247-249.

de Barrera, A.C. and G. Arenas. 1999. Cutting-time effect during harvest cycle on postharvest behavior of three Gypsophila paniculata cv. Perfecta clones. Acta Hort. 482:71-76.

Doi, M. and M.S. Reid. 1995. Sucrose improves the postharvest life of cut flowers of a hybrid Limonium. HortScience 30:1058-1060.

Dole, J.M., P. Fisher, and G. Njue. 2004. Optimizing postharvest life of cut 'Renaissance Red' poinsettias. HortScience 39:1366-1370.

Elgar, H.J., A.B. Woolf, and R.L. Bieleski. 1999. Ethylene production by three lily species and their response to ethylene exposure. Postharvest Biol. Technol. 16:257-267.
Faragher, J.D., S. Mayak, T. Tirosh, and A.H. Havely. 1984. Cold storage of rose flowers: Effect of cold storage and water loss on opening and vase life of 'Mercedes' roses. Scientia Hort. 24:369-378.

Geertsen, V. 1990. The keeping quality of Otacanthus coeruleus: A potential new cut flower. Scientia Hort. 43:145-153.

Heuser, C.W. and K.B. Evensen. 1986. Cut flower longevity of peony. J. Amer. Soc. Hort. Sci. 111:896-899.

Ichimura, K., M. Shimamura, and T. Hisamatsu. 1998. Role of ethylene in senescence of cut Eustoma flowers. Postharvest Biol. Technol. 14:193-198.

Janowska, B. and M. Jerzy. 2004. Effect of gibberellic acid on the post-harvest flower longevity of Zantedeschia elliottiana (W. Wats). Engl. Acta Scientiarum Polonorum Hortorum Cultus 3:3-9.

Jones, R.B. and M. Hill. 1993. The effect of germicides on the longevity of cut flowers. J. Amer. Soc. Hort. Sci. 118: 350-354.

Jones, R.B., J.D. Faragher, and W.G. van Doorn. 1993. Water relations of cut flower in branches of Thryptomene calycina (Lindl.) Stapf. (Myrtaceae). Postharvest Biol. Technol. 3:57-67.

Kamataka. 2003. Chemically fortified solutions to enhance the longevity of cut rose cv. Arjun. J. Agr. Sci. 16:324-326.

Kenza, M., N. Umiel, and A. Borochov. 2000. The involvement of ethylene in the senescence of ranunculus cut flowers. Postharvest Biol. Technol. 19:287-290.

Knee, M. 2000. Selection of biocides for use in floral preservatives. Postharvest Biol. Technol. 18:227-234.

Maclean, I.B. and H.P. Rasmussen. 1980. Graphic display of quantitative and qualitative character associations in cut roses. J. Amer. Soc. Hort. Sci. 105:625-628.

Marissen, N. 2005. Postharvest quality of roses as related to preharvest conditions. Acta Hort. 669:255-262.

Mayak, S., B. Bravdo, A. Gvilli, and A.H. Halevy. 1973. Improvement of opening of cut gladioli flowers by pretreatment with high sugar concentrations. Scientia Hort. 1:357-365.

Nair, S.A., V. Singh, and T.V.R.S. Sharma. 2003. Effect of chemical preservatives on enhancing vase-life of gerbera flowers. J. Trop. Agr. 41:56-58.

Newman, J.P., L.L. Dodge, and M.S. Reid. 1998. Evaluation of ethylene inhibitors for postharvest treatment of Gypso- philla paniculata L. HortTechnology 8:58-63.

Nowak, J. and R.M. Rudnicki. 1990. Postharvest handling and storage of cut flowers, florist greens, and potted plants. Timber Press, Portland, OR.

Redman, P.B., J.M. Dole, N.O. Maness, and J.A. Anderson. 2002. Postharvest handling of nine specialty cut flower species. Scientia Hort. 92:293-303.

Reid, M.S. 2004. Cut flowers and greens. In: K. Gross (ed.). The commercial storage of fruits, vegetables, and florist and nursery stocks. U.S. Dept. Agr. Hdbk. 66. 15 Feb. 2009. <http://www.ba.ars.usda. gov/hb66/148cutflowers.pdf $>$.

Sacalis, J.N. 1993. Cut flowers: Prolonging freshness: Postproduction care and handling, 2nd ed. Ball Publishing, Batavia, IL.

Slootweg, G. 2005. Effects of greenhouse conditions on the quality and vase life of Freesia 'Yvonne'. A nursery comparison. Acta Hort. 669:297-301.

Stimart, D.P., D.J. Brown, and T. Solomos. 1983. Development of flowers and changes in carbon dioxide, ethylene, and various sugars of cut Zinnia elegans Jacq. J. Amer. Soc. Hort. Sci. 108:651-655.

Teagle, S., J. White, and M. Sedgley. 1991. Post-harvest vase life of cut flowers of three cultivars of kangaroo paw. Scientia Hort. 48:277-284.

Valenzuela-Vasquez, M., G.A. Picchioni, L.W. Murray, and W.A. Mackay. 2007. Beneficial role of 1-methylcyclopropene for cut Lupinus havardii racimes exposed to ethephon. HortScience 42:113119.

van Doorn, W.G. and R.R.J. Perik. 1990. Hydroxyquinoline citrate and low $\mathrm{pH}$ prevent vascular blockage in stems of cut rose flowers by reducing the number of bacteria. J. Amer. Soc. Hort. Sci. 115: 979-981.

van Gorsel, R. 1993. Postharvest quality and water relations of bouvardia cut flowers as effected by preharvest temperature and season. Acta Hort. 343:309-312.

van Meeteren, U., H. van Gelder, and W. van Ieperen. 2000. Reconsideration of the use of deionized water as vase water in postharvest experiments on cut flowers. Postharvest Biol. Technol. 17:175-187.

Verlinden, S. and J.J. Vicente Garcia. 2004. Sucrose loading decreases ethylene responsiveness in carnation (Dianthus caryophyllus cv. White Sim) petals. Postharvest Biol. Technol. 31:305-312. 